\title{
LAS IDEAS DE GARCÍA MÁRQUEZ SOBRE EL DICCIONARIO Y EL LÉXICO DEL ESPAÑOL EN NOTAS DE PRENSA 1980-1984
}

\author{
Manuel Cabello Pino \\ Universidad de Huelva
}

A pesar del innegable reconocimiento del que goza hoy día Gabriel García Márquez a nivel mundial como figura representativa de la lengua española, resulta desde luego sorprendente la poca atención que se le ha prestado por parte de los estudiosos e investigadores al análisis de su contribución a esa misma lengua española. Y más llamativo aún resulta si se tiene en cuenta que se trata de una de las figuras culturales del siglo Xx sobre las que se ha acumulado un mayor volumen de estudios que abarcan sus diversas facetas como persona: no solo su obra literaria ha sido ampliamente estudiada desde los más diversos enfoques, sino que también lo han sido su labor periodística y sus trabajos cinematográficos (que desarrolló durante toda su vida de manera paralela a su carrera de escritor). E incluso otras cuestiones que tal vez debieran ser consideradas algo más secundarias, como sus relaciones con la política o la visión sociológica machista o feminista que se plasma en sus obras, han sido estudiadas y debatidas en multitud de artículos y volúmenes.

Sin embargo, son escasísimas las investigaciones que han afrontado el estudio de su figura y de su obra desde el punto de vista de la lengua, cuando son muchos los campos de interés que se pueden encontrar en la relación de García Márquez con la lengua española que debieran ser objeto de estudio. Para empezar, si tal como dice Enrique Serrano se le consideraba un «cuidadoso 
estilista de la lengua»1, un «magnífico orfebre de la lengua»» $\mathrm{y}$ «sus textos se han convertido en joya perdurable de la lengua española» $»^{3}$, entonces no cabe duda de que su propia obra debiera ser objeto de análisis desde las distintas subdisciplinas de estudio de la lengua: la morfología, la sintaxis y, muy especialmente, la lexicografía. Pero la realidad es que a día de hoy siguen siendo aún muy pocos los estudios que se han llevado a cabo dedicados a cualquiera de estas cuestiones.

Más interesante aún parece otra vía de estudio que permanece todavía prácticamente virgen. Y es la que concierne a la recopilación, estudio y análisis de las opiniones e ideas vertidas por el propio Gabriel García Márquez respecto a diversos aspectos de la lengua y, más en concreto, de la lengua española. Si a día de hoy hay un consenso total en el mundo académico en considerar a Gabriel García Márquez un referente absoluto en el manejo del español contemporáneo, equiparable a Cervantes en su época, parece evidente también que, al igual que resulta interesante y ha sido objeto de estudio la concepción de escritores indiscutibles como Cervantes o Mateo Alemán sobre el castellano de su época, lo sea también la de escritores contemporáneos de la importancia de García Márquez o Mario Vargas Llosa. Sobre todo, porque son escritores que, con su manera de utilizar la lengua española en sus obras, pero también con las opiniones que han vertido en ocasiones sobre ella, han tenido y todo apunta a que van a seguir teniendo en los próximos años una gran influencia en el devenir del español, no solo a nivel popular sino, más importante aún, a nivel normativo.

Un ejemplo perfecto de esto lo encontramos en la conocida polémica que se generó en 1997 con el famoso discurso Botella al mar para el dios de las palabras que pronunció Gabriel García Márquez en la inauguración del I Congreso de la Lengua Española celebrado en Zacatecas, México, con su revolucionaria propuesta de «jubilar la ortografía». Es ese, por supuesto, el aspecto de las relaciones entre García Márquez y la lengua española que ha sido más

${ }^{1}$ E. Serrano, «Recepción del legado garciamarquiano», Boletín cultural y bibliográfico, XLVIII, 85, 2014, 25-37, pág. 25.

${ }^{2}$ E. Serrano, loc. cit.

${ }^{3}$ E. Serrano, loc. cit., pág. 30.

${ }^{4}$ Solamente en el campo de la lexicografía ha habido algunos intentos serios de análisis de su obra y su contribución. El precursor es, sin duda, el estudio de Milagros Aleza y Joaquín García Medall («Observaciones diacrónicas sobre el léxico utilizado por Gabriel García Márquez», en M. Ariza et alii, eds., Actas del II Congreso Internacional de Historia de la Lengua Española, II, Pabellón de España, Madrid, 1992, págs. 303-311), intento loable pero claramente insuficiente. Algunos años más tarde Margret de Oliveira publicó La lengua ladina de García Márquez (Panamericana Pub. Llc., 2007), un libro que recoge más de dos mil palabras de la obra del escritor colombiano que pueden ser de difícil comprensión para un lector de cualquier latitud. Y la misma autora publicó en colaboración con Conrado Zuluaga Osorio («A ambos lados del Atlántico con García Márquez», Boletín cultural y bibliográfico, XLVIII, 85, 2014, págs. 39-53), un breve artículo de homenaje en el que se hace un repaso somero por la utilización variada del léxico del español de América por parte de García Márquez en sus obras. 
ampliamente tratado hasta la fecha. Pero lo ha sido sobre todo desde el punto de vista periodístico, con encendidos debates en artículos y notas de prensa que comenzaron en la época inmediatamente posterior al discurso, pero que han llegado vivos hasta nuestros días, casi veinte años después ${ }^{5}$. Sin embargo, ha habido pocos intentos serios de estudiar el contenido real de aquel discurso de García Márquez desde una perspectiva académica ${ }^{6} \mathrm{y}$, desde luego, ninguno que se haya propuesto determinar hasta qué punto el contenido de la propuesta de renovación /simplificación ortográfica de García Márquez ha tenido alguna influencia en las sucesivas reformas ortográficas que han ido haciendo las Academias de la Lengua Española en los últimos años.

Sin embargo, hay otras perspectivas quizá menos mediáticas, pero desde luego igualmente interesantes acerca de las ideas de Gabriel García Márquez sobre la lengua española sobre las que aún está todo por hacer. En este sentido, el presente artículo pretende arrojar algo de luz sobre un aspecto de la relación entre García Márquez y la lengua española que ha pasado completamente desapercibido hasta hoy para los estudiosos y que, sin embargo, como se demostrará a lo largo de las próximas páginas, es muy interesante: se trata de la intensa relación que estableció Gabriel García Márquez a lo largo de toda su vida con el diccionario (con el sentido del objeto genérico) y con los diccionarios (con el sentido de los distintos tipos: lexicones, diccionarios de uso, etc. y de distintas filiaciones y procedencias: Diccionario de la Real Academia Española de la Lengua ${ }^{7}$, María Moliner, Corominas, Vox, Petit Larousse, Diccionario de Autoridades...). Esta relación le llevó a desarrollar sus propias ideas respecto al diccionario que no dudó en plasmar, aunque de forma bastante dispersa, en algunos de sus escritos periodísticos, discursos que pronunció en los más variados foros y declaraciones varias a los medios a lo largo de los años.

Este trabajo se ha centrado en el análisis de las referencias al diccionario que se pueden encontrar en las notas de prensa que escribió semanalmente en el periodo comprendido entre 1980 y 1984, por ser la época de su vida en la que pareció mostrar un mayor interés por tomar la palabra en primera persona y exponer sus opiniones e ideas al respecto. En último término, este artículo

5 Véase, por citar solo algunos, J. Estefanía, «De camisas de fuerza y cinturones de castidad», El país 13/04/1997; M. Rico, «Cela y García Márquez arremeten contra los intentos de constreñir el idioma», El país 8/04/1997; D. Villanueva, «García Márquez hizo temblar los muros», $A B C$ 20/04/2014.

${ }^{6}$ Uno de los más rigurosos es el artículo de R. Sánchez García y M. Jiménez Mañas, «Botella al mar para el dios de las palabras. Reflexiones de García Márquez sobre gramática y ortografía», Álabe, 6, 2012.

${ }^{7}$ En adelante se hará referencia a él como DRAE, pues esa es la denominación que tenía en vida de García Márquez. Cada vez que el escritor de Aracataca menciona en estas notas de prensa el Diccionario de la Real Academia Española se está refiriendo, sin duda, a la 19. edición, publicada en 1970, pues hasta 1984 no apareció la 20a edición, siendo la última nota en la que se hace referencia a dicho diccionario del 21 de diciembre de 1983. A partir de la 23. edición, publicada en 2014 pasaría a denominarse Diccionario de la lengua española DLE. 
tratará de demostrar que existe una teoría garciamarquiana sobre los diccionarios que, aunque él mismo no se preocupara nunca de armar y estructurar, está sin duda latente en esos textos ${ }^{8}$.

Pero probablemente es imposible entender de dónde proceden esas ideas si no se es consciente de la importancia que tuvo el diccionario en la vida y obra del premio Nobel colombiano.

\section{EI diccionario: el gran compañero de García Márquez}

Algunos de los más importantes escritores en lengua castellana del siglo XX han quedado de alguna forma indisolublemente ligados en el imaginario colectivo a la figura del diccionario. Por ejemplo, el poeta chileno Pablo Neruda que, con la publicación de su famosa Oda al diccionario, recogida en Nuevas odas elementales (1956), dejó uno de los más divertidos y certeros retratos que se hayan hecho nunca sobre el libro de las palabras. $\mathrm{O}$ el argentino Jorge Luis Borges, «el hombre que había leído todos los libros» y que acumulaba un saber enciclopédico sin igual, quien en 1985 escribió el «Prefacio a un diccionario» para el Diccionario enciclopédico Grijalbo. Aunque, tal vez, el caso más llamativo sea el del escritor español Camilo José Cela, que llegó a escribir dos diccionarios muy personales: primero publicó su Diccionario secreto en dos partes, el Tomo I que apareció en 1968 y el Tomo II que lo hizo en 1971; y casi treinta años más tarde, en 1998, apareció su Diccionario geográfico popular de España.

Sin embargo, resulta sorprendente que Gabriel García Márquez no suela ser asociado con el diccionario cuando pocos escritores han reconocido abiertamente tener una deuda tan grande con él y, desde luego, muy pocos han hablado y escrito tan profusamente sobre él9. Solo los buenos conocedores de la vida y obra (especialmente periodística) del escritor colombiano, solo los muy iniciados en sus estudios, están al tanto de la importancia capital que el diccionario tuvo en él, hasta alcanzar la categoría de auténtica obsesión. Obsesión por los diccionarios que parece ser que le acompañó hasta sus últimos años, como atestigua el hecho de que, en 1996, con motivo del setenta cumpleaños de Fidel Castro, el escritor colombiano le regalara un ejemplar

${ }^{8}$ De hecho, este artículo debe leerse como un díptico junto con M. Cabello Pino, «García Márquez sobre el diccionario y el léxico del español: análisis del "Prólogo" al Clave. Diccionario de uso del español actual», Lingüística y Literatura, 77, 41, 2020, al final del cual, y una vez anali-zadas tanto las notas de prensa que tratamos en este artículo como el «Prólogo» al Clave, sintetizamos los ocho puntos que estructuran las teorías garciamarquianas sobre el léxico y los diccionarios.

${ }^{9}$ Tal es así que, aunque casi nadie lo recuerde, llegó a escribir el prólogo de un diccionario, el Clave. Diccionario de uso del español actual (1996). Un detallado análisis de dicho texto desde la perspectiva de las ideas que expresa sobre el diccionario y el léxico del español puede encontrarse en M. Cabello Pino, loc. cit. 
del nuevo diccionario elaborado por el instituto de la lengua de Colombia, el Instituto Caro y Cuervo ${ }^{10}$.

Dicha obsesión surgió ya en su infancia en la aldea de Aracataca en la década de 1930 del siglo pasado y parece ser que fue su abuelo, el coronel Nicolás Márquez, quien le inculcó la buena costumbre de consultar siempre el diccionario para conocer el significado de las palabras que desconocía. Tal como explicaba ya en 1982 su íntimo amigo Plinio Apuleyo Mendoza:

El viejo y parsimonioso coronel concedía a su nieto la mayor importancia. Le escuchaba, respondía sus preguntas. Cuando no sabía contestarle, le decía: «Vamos a ver qué dice el diccionario». (Desde entonces, Gabriel aprendió a mirar con respeto aquel libro polvoriento que contenía la respuesta a tantos enigmas) ${ }^{11}$.

A partir de entonces, no solo miró con respeto aquel libro, sino que, ya adulto, lo incorporó a su rutina diaria de periodista y escritor y fue haciendo acopio de ellos para su trabajo, de manera que, como también afirma Mendoza, «Sus instrumentos de trabajo son media docena de diccionarios $[\ldots] \gg^{12}$.

A priori, podría resultar aparentemente contradictorio el hecho de que un escritor especialmente reconocido y admirado por su gran conocimiento y riquísimo uso del léxico del español, como para hacer que haya sido calificado en alguna ocasión como un «lexicógrafo de altos vuelos» $»^{13}$, tuviera realmente tal dependencia del diccionario. Sin embargo, no debe resultar extraño que los diccionarios se convirtieran en una de sus principales herramientas de trabajo, si se tienen en cuenta las palabras que el propio García Márquez escribió sobre sí mismo a finales de la década de 1960 para explicar su método de trabajo al componer sus libros:

En mi caso el ser escritor es un mérito descomunal, porque soy muy bruto para escribir. He tenido que someterme a una disciplina atroz para terminar media página en ocho horas de trabajo; peleo a trompadas con cada palabra y casi siempre es ella quien sale ganando, pero soy tan testarudo que he logrado publicar cinco libros en veinte años ${ }^{14}$.

Pero quizá la descripción que hace Enrique Serrano del método de trabajo de García Márquez con el léxico en sus obras nos permita comprender aún mejor la magnitud de la deuda contraída con el diccionario a lo largo de su carrera por el escritor de Aracataca:

${ }^{10}$ G. Martin, Gabriel García Márquez. Una vida (trad. de E. Vázquez Nacarino), Random House Mondadori, Barcelona, 2009, pág. 583.

${ }^{11}$ P. A. Mendoza y G. García Márquez, El olor de la guayaba, Mondadori, Barcelona, 1994, pág. 15.

12 P. A. Mendoza y G. García Márquez, loc. cit., pág. 117.

${ }^{13}$ E. Serrano, op. cit., pág. 25

${ }^{14}$ A. D’Amico y S. Facio, Retratos y autorretratos, Crisis, Buenos Aires, 1973. 
Cada palabra soez, en donde la haya, ha sido cuidadosamente preparada y «situada» para que no produzca un efecto envilecedor, sino para que refuerce la emoción y realce la potencia de la prosa. Cada expresión fuerte o picante se halla dentro de un ámbito definido y deliberadamente explorado para garantizar su uso y elevar su significado.

Los adjetivos también han sido tratados con el cuidado necesario para evitar caer en la trampa de una redacción hiperbólica. Cuando alguna palabra nueva aparece se forma a su alrededor una suerte de tensión, de modo que nunca queda sin ser explicada o referida al contexto en el que pueda alcanzar mayor eficacia. La ausencia de gratuidad que hay en esta práctica comporta una forma de ideal caballeresco de la escritura, por el cual todo debe ser aclarado en caliente, con la prontitud y la precisión necesarias $^{15}$.

Al igual que sucede con esta otra explicación proporcionada por dos de los mayores estudiosos de la obra del escritor de Aracataca, Conrado Zuluaga Osorio y Margret de Oliveira, quienes afirman que:

García Márquez hace acopio de todas las palabras que encuentra, ya sea las aprendidas en sus incansables lecturas, las almacenadas en su prodigiosa memoria, las encontradas en los diccionarios, las adoptadas en los diferentes países... y siempre las emplea de manera oportuna y con discernimiento porque, al fin y al cabo, la cuestión no se reduce a disponer de un amplio léxico, de un variado arsenal de palabras, sino de disponer del talento y la sabiduría para usarlas en el momento apropiado. El acopio es un asunto de estudio y carpintería, pero su uso es una cuestión de talento, de creatividad y de maestría ${ }^{16}$.

Es, desde luego, en esa parte de acopio, de estudio y de carpintería de las palabras en la que el diccionario y su constante consulta han tenido una grandísima importancia en la carrera como escritor de García Márquez. Y esto es algo de lo que él siempre hizo gala más que cualquier otro escritor de su talla, pues, lejos de intentar disimular la influencia decisiva que dicho libro había tenido en su trabajo como escritor (y por extensión en su formación como persona), el premio Nobel colombiano nunca dejó pasar la oportunidad de hablar de ello públicamente. Y como se verá en este trabajo, no se limitó solo a reconocer abiertamente su deuda con el diccionario, sino que el contacto diario con su principal instrumento de trabajo le fue llevando a reflexionar detenidamente a lo largo de los años sobre la naturaleza del mismo, sobre sus virtudes y sus inconvenientes, sus problemas, sus carencias y a ir plasmando todas estas preocupaciones en diversos textos que se analizarán en este trabajo.

Pero, como conclusión de este apartado, sirva la siguiente anécdota para ilustrar de forma definitiva lo que el diccionario supuso en la vida y obra

\footnotetext{
${ }^{15}$ E. Serrano, op. cit., pág. 36.

${ }^{16}$ C. Zuluaga Osorio y M. de Oliveira, op. cit., pág. 53.
} 
de Gabriel García Márquez: según contaba el propio escritor de Aracataca, en una ocasión la revista Pluma de Bogotá le preguntó a un grupo de escritores cuáles habían sido los cinco libros más significativos para ellos. García Márquez escogió Las mil y una noches, Edipo rey, de Sófocles, Moby Dick, de Melville, la antología de José María Blecua Floresta de la lírica española y, sorprendentemente, un Diccionario de la lengua castellana. Según él, «si sólo hubiera leído esos cinco libros — además de los obvios, desde luego-, con ellos me habría bastado para escribir lo que he escrito» ${ }^{17}$. De todos los escritores entrevistados fue el único que incluyó un diccionario.

\section{Notas de prensa 1980-1984}

Gabriel García Márquez escribió durante casi cuatro años, entre septiembre de 1980 y marzo de 1984, una serie de notas de prensa que fue publicando semanalmente en destacados periódicos como El Espectador de Bogotá y El País de Madrid, así como en otros periódicos de América Latina y Europa. Estas, que fueron recopiladas y publicadas como libro en 1991 por la editorial Mondadori, constituyen sin duda un documento valiosísimo para conocer el pensamiento garciamarquiano sobre los más variados temas, desde la política a la literatura o el cine, pasando por cualquier aspecto de la vida diaria. Debería ser, por lo tanto, uno de los libros de cabecera de quienes investiguen cualquier aspecto del pensamiento del escritor de Aracataca, pues en ellas, con la libertad que le otorgaba el formato nota de prensa, que se presta a un estilo anecdótico y desenfadado frente a la formalidad y rigidez del género del ensayo, García Márquez habla de múltiples temas.

El propio novelista explicaba perfectamente su intención en una de esas notas de prensa publicada en octubre de 1982 y titulada «Se necesita un escritor». En sus propias palabras:

Mi primer propósito con estas notas es que cada semana les enseñen algo a los lectores comunes y corrientes, que son los que me interesan, aunque esas enseñanzas les parezcan obvias y tal vez pueriles a los sabios doctores que todo lo saben ${ }^{18}$.

Se puede apreciar cómo García Márquez muestra un desprecio abierto y claro hacia el mundo de los académicos y de los intelectuales, desprecio que, paradójicamente, podría surgir tal vez de un cierto complejo de inferioridad motivado sin duda por el estigma que le supuso siempre su escasa formación reglada. Con estas notas quería expresar su pensamiento con total libertad y enseñar a la gente cosas que creía que podían ser importantes. Pero era plenamente consciente de que él no era Doctor en Letras como Vargas Llosa, no

\footnotetext{
${ }^{17}$ G. García Márquez, Notas de prensa 1980-1984, Mondadori Espasa, Madrid, 1991, pág. 348

18 G. García Márquez, loc. cit., págs. 320-321.
} 
escribía ensayos para la comunidad académica como Carlos Fuentes y, sin embargo, sabía que por la fama y el prestigio internacional que había adquirido como escritor, estas notas iban a ser leídas y analizadas por esa comunidad académica y quería prevenir las posibles críticas, dejando claro que no iban dirigidas a ellos sino a la gente común. Sin embargo, este modesto propósito no les resta valor en absoluto, como se va a demostrar a continuación.

Las notas de prensa escritas por García Márquez en el periodo comprendido entre 1980 y 1984 resultan de gran valor para los estudiosos de la lengua, porque uno de los temas que trató más profusamente en esas notas fue precisamente la lengua española. Diseminadas por esas notas de prensa hay numerosas referencias a diversos aspectos de aquello que, sin duda, constituía su instrumento de trabajo diario. Pero, sin lugar a dudas, de entre todas las referencias a la lengua española los temas más repetidos por el escritor de Aracataca son el léxico del español y, por supuesto, el diccionario. De las ciento setenta y tres notas que publicó durante ese periodo, en al menos once de ellas menciona los diccionarios ${ }^{19} \mathrm{y}$, en concreto, tres de esas notas están dedicadas por entero a hablar de diccionarios, lo cual supone sin duda un porcentaje bastante llamativo para tratarse de un tema que se podría considerar tan secundario para sus lectores. Tales notas son «La mujer que escribió un diccionario», «Un diccionario de la vida real» y «La vaina de los diccionarios», si bien la segunda de ellas, a diferencia de las otras dos, tiene un interés nulo para determinar la visión particular de García Márquez sobre los diccionarios de la lengua en general y sobre el $D R A E$ en particular, ya que se centra en realidad en una especie de pequeño diccionario enciclopédico. Por su parte, las notas tituladas «La conduerma de las palabras» y «Algo más sobre literatura y realidad» están dedicadas por entero a hablar de cuestiones relacionadas con el léxico del español.

Se dejará para más adelante el análisis de esas notas enteramente dedicadas a los diccionarios, para empezar analizando aquellas otras alusiones a los mismos que están dispersas en notas que no están específicamente centradas en el tema de los diccionarios, ya que incluso de esas referencias más dispersas se pueden extraer conclusiones interesantes sobre las ideas del Premio Nobel colombiano acerca de diccionarios y léxico.

En varias de las once notas a las que se ha aludido anteriormente la referencia al diccionario viene motivada por pretender el autor explicar o aclarar el significado de alguna palabra, para lo cual no duda nunca en decirles a los lectores cuál es la definición que da el diccionario de ella, empezando casi siempre por el de la Real Academia Española de la Lengua. Tal es el caso, por ejemplo, de la nota titulada «Frases de la vida», en la que trata, como su propio nombre indica, de expresiones populares muy conocidas. Cuando hace

${ }_{19}$ La lista completa en orden cronológico es: «La mujer que escribió un diccionario» (10/02/81); «La conduerma de las palabras» (19/05/81); «Fantasía y creación artística» (9/06/81); «Bogotá 1947» (21/10/81); Un diccionario de la vida real (18/11/81); «Cuentos de caminos» (27/01/82); «La vaina de los diccionarios» (19/05/82); «Está de moda ser delgado» (30/06/82); «Frases de la vida» (18/08/82); «La literatura sin dolor» (8/12/82); «Vuelta a la semilla» (21/12/83). 
referencia a la expresión «Es de las que confunden el culo con las témporas» García Márquez reconoce que:

Durante muchos años lo oí decir, y nunca tuve el cuidado de averiguar qué eran las témporas, hasta hace muy poco tiempo, cuando una necesidad del oficio me obligó a preguntárselo al diccionario, y éste me contestó: «Tiempo de ayuno que prescribe la Iglesia en las cuatro estaciones $\gg 20$

Algo parecido sucede con la nota titulada «Vuelta a la semilla», en la que explica que:

La palabra - animes - es un misterio que me persigue desde aquellos tiempos. El Diccionario de la Real Academia dice que el anime es una planta y su resina. De igual modo define esta voz, aunque con muchas más precisiones, el excelente lexicón de colombianismos de Mario Alario di Filippo. El padre Pedro María Revollo, en sus Costeñismos colombianos, ni siquiera la menciona. En cambio, Sundenheim, en su Vocabulario costeño, publicado en 1922 y al parecer olvidado para siempre, le consagra una nota muy amplia que transcribo en la parte que más nos interesa: «El anime, entre nosotros, es una especie de duende bienhechor que auxilia a sus protegidos en lances difíciles y apurados, y de ahí que cuando se afirme de alguien que tiene animes se dé a entender que cuenta con alguna persona o fuerza misteriosa que le ha prestado su concurso». Es decir, Sundenheim los identifica con los duendes, y de modo más preciso, con los descritos por Michelet ${ }^{21}$.

De este párrafo se pueden deducir varias cuestiones interesantes: la primera es que confirma que García Márquez no sólo tenía numerosos diccionarios, como ya se vio que afirmaba su amigo Plinio Apuleyo Mendoza, sino que además los utilizaba con profusión y se movía con soltura entre ellos ${ }^{22}$. La segunda es que entre esos diccionarios los había más generales, como el $D R A E$, y los había también más específicos, como los diversos lexicones de vocabulario regional que menciona. Pero, además, se observa aquí también un procedimiento que se repetirá siempre en cada ocasión en que García Márquez quiere hablarles a sus lectores sobre el significado de una palabra concreta, que consiste en ir de la fuente de consulta más general y reconocida a las más particulares y específicas. Siempre, sin excepción, empieza por decir a los lectores qué significado le otorga el DRAE a un determinado término, solo

${ }^{20}$ G. García Márquez, loc. cit., pág. 302.

${ }^{21}$ G. García Márquez, loc. cit., pág. 506.

22 Algo que también se puede deducir de otra nota titulada «Cuentos de caminos» publicada el 27 de noviembre de 1982 en la que, hablando precisamente de esa expresión, García Márquez se queja de que, a pesar de conocerla desde siempre, es «una expresión que ahora no he podido encontrar en tantos y tantos diccionarios inútiles como tengo en mi biblioteca» (G. García Márquez, loc. cit., pág. 218). 
para inmediatamente pasar a desechar dicha definición como la peor posible. A continuación, pasa a aclarar lo que otros diccionarios o lexicones menos conocidos tienen que decir sobre el término, generalmente también con resultados desilusionantes para él. En este caso, como se trata de un regionalismo, tras el DRAE, consulta primero un diccionario de léxico colombiano en general y, después, otros dos ya mucho más específicos sobre léxico costeño, es decir, sobre términos específicos de la región de su país que da al mar Caribe que, como es bien sabido, era su tierra natal. Debido a que en la mayoría de las ocasiones en que García Márquez hace referencia en estas notas de prensa al significado de alguna palabra en concreto es porque para él su significado no coincide exactamente con el que le otorgan los diccionarios, siempre suele acabar por explicarles a sus lectores cuál entiende que es la acepción con la que él conoce el término. Tal y como hace aquí cuando, tras todo lo dicho en la cita anterior, prosigue explicando que:

Los animes de Aracataca eran otra cosa: unos seres minúsculos, de no más de una pulgada, que vivían en el fondo de las tinajas. A veces se les confundía con los gusarapos, que algunos llamaban sarapicos, y que eran en realidad las larvas de los mosquitos jugueteando en el fondo del agua de beber. Pero los buenos conocedores no los confundían: los animes tenían la facultad de escapar de su refugio natural, aun si la tinaja se tapaba con buen seguro, y se divertían haciendo toda clase de travesuras en la casa. No eran más que eso: espíritus traviesos, pero benévolos, que cortaban la leche, cambiaban el color de los ojos de los niños, oxidaban las cerraduras o causaban sueños enrevesados. Sin embargo, había épocas en que se les trastornaba el humor, por razones que nunca fueron comprensibles, y les daba por apedrear la casa donde vivían ${ }^{23}$.

Como se puede observar, para explicar el significado de un término, lejos de intentar ser académico, exhaustivo y riguroso, recurre por el contrario como siempre a lo anecdótico, a lo subjetivo, a lo que puede evocar un término. Una cuestión esta del significado subjetivo de las palabras que, como se verá más adelante en este mismo trabajo, trataría García Márquez con mayor profusión en otra nota titulada «La vaina de los diccionarios».

Mucho más reveladora acerca de su postura respecto a los diccionarios, sin duda, resulta la nota titulada «Bogotá 1947», en la que asegura que una vez vio que se subía al tranvía en el que él iba montado un fauno. Lo primero que hace en ese momento García Márquez en su nota es dar al lector la definición de la palabra «fauno» que viene en el DRAE, solo para darnos a entender que, para él, se trata de una pésima definición. Así nos dice que:

Según el diccionario de la Real Academia Española, un fauno es «un semidios de los campos y las selvas ${ }^{24}$. Cada vez que releo esta definición

\footnotetext{
${ }^{23}$ R. García, loc. cit., pág. 506.

${ }^{24}$ R. García, loc. cit., pág. 172.
} 
desdichada lamento que su autor no hubiera estado allí aquella noche en que un fauno de carne y hueso subió en el tranvía.

Con estas palabras García Márquez nos da a entender que para él un fauno no tiene por qué estar limitado al ámbito de los campos y de las selvas, sino que puede aparecer también perfectamente en un espacio urbano como es un tranvía de una ciudad como Bogotá. De hecho, el escritor colombiano pasa a continuación a darnos la descripción de cómo era el que él vio:

Iba vestido a la moda de la época, como un señor canciller que regresara de un funeral, pero lo delataban sus cuernos de becerro y sus barbas de chivo, y las pezuñas muy bien cuidadas por debajo del pantalón de fantasía. El aire se impregnó de su fragancia personal, pero nadie pareció advertir que era agua de lavanda, tal vez porque el mismo diccionario había repudiado la palabra lavanda como un galicismo para querer decir agua de espliego ${ }^{25}$.

Se puede apreciar cómo al final del párrafo García Márquez no puede resistirse a lanzar otro dardo al $D R A E$ por repudiar la utilización de una palabra como lavanda, que él considera como la de uso más natural para describir una fragancia concreta, señalando así el carácter represor que para él tiene dicho diccionario. En esta crítica al aspecto normativo e impositivo de los diccionarios también profundizaría el escritor de Aracataca en notas posteriores más específicamente dedicadas al diccionario como «La vaina de los diccionarios», que se analizará más adelante.

Como se irá viendo, esta es la tendencia general cada vez que el escritor de Aracataca hace referencia a la mayoría de diccionarios, pero sobre todo y con especial obsesión, cada vez que se refiere al de la Real Academia Española. Algunas veces el dardo contra el DRAE es más sutil como el que se acaba de ver o como, por ejemplo, el que lanza en la nota titulada «Está de moda ser delgado», de octubre de 1982, donde hablando de los artículos de prensa más leídos comenta:

Ahora lo son los que hablan de la dieta, entendida ésta como las restricciones alimenticias para adelgazar y no como «un régimen que se manda observar a los enfermos o convalecientes en el comer y el beber», según la inefable descripción del diccionario de la Academia ${ }^{26}$.

Evidentemente, la utilización aquí del adjetivo inefable para la definición del DRAE no es gratuita, sino que, por el contrario, está utilizado con una nada disimulada carga de sarcasmo. Pero otras veces las invectivas de García Márquez contra la Academia y su diccionario no tienen nada de sutiles. Desde

\footnotetext{
${ }^{25}$ R. García, loc. cit.

${ }^{26}$ R. García, loc. cit., pág. 280.
} 
luego, una de las referencias más reveladoras sobre el pensamiento de García Márquez respecto al DRAE y su posición ante él es la que aparece en la nota titulada «Fantasía y creación artística», en la que comienza:

Según el diccionario de la Real Academia de la Lengua, la fantasía es «una facultad que tiene el ánimo de reproducir por medio de imágenes». Es difícil concebir una definición más pobre y confusa que esa primera acepción. En su segunda acepción dice que es «una ficción, cuento o novela, o pensamiento elevado o ingenioso», lo cual no hace sino infundir mayor desconcierto en el ya creado por la definición inicial.

De la palabra imaginación, el mismo diccionario dice que es «aprensión falsa de una cosa que no hay en la realidad o no tiene fundamento $»^{27}$.

Como se puede comprobar, ya en este primer párrafo cualquier lector mínimamente avezado puede percibir sin dificultad que, si García Márquez cita aquí las definiciones del DRAE de la palabra fantasía no es precisamente para ponerlas como ejemplo de buenas definiciones, sino todo lo contrario, pues cataloga la primera acepción de «pobre y confusa» y de la segunda dice que solo consigue aumentar el desconcierto de la primera ${ }^{28}$. Ante estas primeras definiciones que no le convencen, el escritor colombiano explica a continuación la que da el diccionario de Joan Corominas ${ }^{29} \mathrm{y}$, por contraste, resulta tremendamente revelador que, aunque tampoco parezca quedar muy satisfecho con esta ${ }^{30}$, aluda a su autor en términos claramente laudatorios al denominarlo «ese gran detective de las palabras castellanas» ${ }^{31}$. Para rematar la crítica al $D R A E$ el autor de Aracataca realiza la siguiente afirmación:

Por una vez que he tenido la curiosidad de volver a él para establecer las diferencias entre fantasía e imaginación, me encuentro con la desgracia de que sus definiciones no sólo son muy poco comprensibles, sino que además están al revés.

Y prosigue pasando a explicar el significado de ambas palabras según él las entiende, que es justo al revés de cómo las define la RAE:

${ }^{27}$ R. García, loc. cit., pág. 113.

${ }^{28}$ En este caso, a pesar de la crítica tan directa a la $R A E$ por lo confuso de ambas definiciones en la 19a edición del $D R A E$ (1970), ambos términos siguen definidos prácticamente en los mismos términos en la 23. edición del DLE (2014).

${ }^{29}$ Teniendo en cuenta la estrecha relación que hemos visto que tenía García Márquez con los diccionarios, lo más probable es que cuando habla del diccionario de Joan Corominas en una nota de junio de 1981 se esté refiriendo al Diccionario crítico etimológico de la lengua castellana, Madrid, Gredos, elaborado por Corominas en colaboración con José Antonio Pascual y que empezó a publicarse a partir de 1980.

${ }^{30}$ Según dice en su nota, Corominas «estableció que fantasía e imaginación tienen el mismo origen y que en última instancia puede decirse sin mucho esfuerzo que son la misma cosa» García Márquez, op. cit., pág. 313.

${ }^{31}$ R. García Márquez, loc. cit. 
Quiero decir que, según yo lo entiendo, la fantasía es la que no tiene nada que ver con la realidad del mundo en que vivimos: es pura invención fantástica, un infundio, y por cierto de un gusto poco recomendable en las bellas artes, como muy bien lo entendió el que le puso el nombre al chaleco de fantasía. Por muy fantástica que sea la concepción de que un hombre amanezca convertido en un gigantesco insecto, a nadie se le ocurriría decir que la fantasía sea la virtud creativa de Franz Kafka, y en cambio no cabe duda que fue el recurso primordial de Walt Disney. Por el contrario, y al revés de lo que dice el diccionario, pienso que la imaginación es una facultad especial que tienen los artistas para crear una realidad nueva a partir de la realidad en que viven ${ }^{32}$.

Desde una perspectiva de análisis glotopolítico, este último párrafo resulta enormemente significativo, pues demuestra al menos dos cosas muy importantes: en primer lugar, que a pesar de su obsesión desde la infancia con los diccionarios y con el acto de consultar de manera casi ritual las palabras en él, la actitud de García Márquez ante el mismo no era ni mucho menos de sometimiento ante lo que los académicos decían que debían significar las palabras, sino todo lo contrario. Explican Elvira Narvaja de Arnoux y José del Valle que:

El lugar que un individuo ocupe en la sociedad, los espacios a los que tenga acceso y la capacidad que posea para negociar su rol en ese entorno determinarán su predisposición a actuar de una cierta manera o a valorar de uno u otro modo las acciones de otros - el individuo desarrolla, en terminología de Pierre Bourdieu, un habitus - Estará por tanto en disposición de usar una o varias lenguas, una u otra lengua, una u otra variedad de una lengua, dependiendo de su ubicación y capacidad de maniobra en el complejo entramado social. Y de esta misma posición - y por tanto de su grado de sometimiento o autonomía con respecto al régimen de normatividad imperante- dependerá su disposición a valorar de un modo u otro el espectro de prácticas lingüísticas que se encuentre ${ }^{33}$.

En este sentido, no cabe la menor duda de que la posición privilegiada que ocupaba García Márquez en la sociedad hispanohablante de la época le permitía una autonomía respecto al régimen de normatividad imperante que representaban la RAE y su diccionario, de modo que el escritor de Aracataca no vacilaba en convertirse en un diletante, en un insumiso cuando no estaba de acuerdo con lo que los académicos habían determinado que debía significar una palabra.

Y lo segundo y más importante aún que demuestra la explicación de García Márquez sobre los términos imaginación y fantasía es que el premio Nobel

32 R. García Márquez, loc. cit.

33 E. Narvaja de Arnoux y J. del Valle, «Las representaciones ideológicas del lenguaje: discurso glotopolítico y panhispanismo», Spanish in Context, 7, 1, 2010, pág. 2. 
colombiano no se conformaba con llevar a cabo esa insumisión de manera indirecta o encubierta, es decir, utilizando las palabras en su obra con el significado que él entendía que tenían (aunque no coincidieran con el que les diera la RAE), sino que él sentía la necesidad de hacer pública y notoria su discrepancia con lo que para él eran desatinos definitorios de la Academia. Y lo que es más, no dudaba en tratar de enmendar dichos desatinos, procediendo a definir los términos en cuestión tal como él mismo los concebía. En última instancia, podríamos decir que no tenía miedo a convertirse él mismo en lexicógrafo ocasional y, lo que es más importante aún, a diferencia de otros escritores contemporáneos suyos, no tenía miedo a enfrentarse públicamente a la Academia ${ }^{34}$, inscribiéndose así en una larga tradición de críticas a la institución decimonónica $^{35}$. También en esta actitud de desautorizar a los académicos como dueños y señores únicos del significado de las palabras profundizaría más García Márquez en sus dos notas enteramente dedicadas al diccionario, «La mujer que escribió un diccionario» $\mathrm{y}$ «La vaina de los diccionarios».

El escritor colombiano, haciendo gala por un lado de una falsa modestia al reconocer sus carencias intelectuales, pero por otro lado sintiéndose respaldado, sin lugar a dudas, por la inmensa admiración que había conseguido en todo el mundo ya para esta época previa al Nobel, no dejaba asomo de dudas al establecer en esa misma nota de prensa que:

Uno de mis mayores defectos intelectuales es que nunca he logrado entender lo que quieren decir los diccionarios, y menos que cualquier otro el terrible esperpento represivo de la Academia de la Lengua ${ }^{36}$.

Como acabamos de mencionar, las críticas a la RAE han sido históricamente una constante casi desde su fundación y lo siguen siendo hoy día. Esas críticas responden a numerosos motivos y provienen tanto de ámbitos sociales como del propio mundo de los especialistas en lengua y lingüística. Por ejemplo, se ha acusado muchas veces a la RAE de tener un carácter sexista, de modo que importantes figuras sociopolíticas tales como la Directora del Instituto Andaluz de la Mujer, Soledad Ruiz, han cargado a veces duramente contra la RAE porque dicha institución intenta «invisibilizar a las mujeres, en un lenguaje tan rico como el español, que tiene masculino y femenino» ${ }^{37}$. Y, por supuesto, reconocidas lingüistas y especialistas en el campo del sexismo lingüístico como Mercedes Bengoechea o Eulalia Lledó, han criticado abiertamente en

${ }^{34}$ Actitud antiacadémica, por cierto, que iría haciéndose más clara y notoria con los años hasta su culminación con la famosa polémica generada en 1997 por su no menos famoso discurso Botella al mar para el dios de las palabras en el Congreso de la Lengua Española celebrado en Zacatecas (México).

35 Sobre este particular véase L. C. Díaz Salgado, «Historia crítica y rosa de la Real Academia Española», en S. Senz y M. Alberte (eds.), El dardo en la Academia. Esencia y vigencia de las academias de la lengua española, I, Melusina, Barcelona, 2011, págs. 21-157.

${ }^{36}$ R. García Márquez, op. cit., pág. 113.

37 J. C. Díaz Salgado, op. cit., págs. 114-115. 
numerosas ocasiones a la RAE. Asimismo, se ha acusado, en especial en los últimos tiempos, a la RAE de tener una visión tremendamente nacionalista de la lengua española. En esta crítica destacan voces tan reconocidas dentro de la lingüística como la de Juan Carlos Moreno Cabrera ${ }^{38}$. Sin embargo, esas críticas se han hecho siempre en unos términos que denotan que, aunque se pueda estar en desacuerdo con ella, se le sigue teniendo un cierto respeto a la institución. Quizá solo un escritor con el estatus privilegiado del que gozaba García Márquez en la época podría atreverse a calificar públicamente al diccionario de la RAE con unos términos tan duros y claros como «terrible esperpento represivo». Como ya se ha ido mostrando, la hostilidad hacia el DRAE fue una constante casi obsesiva en el escritor colombiano. Pero esta actitud que aquí aparece todavía de forma indirecta, de manera que es el lector el que tiene que extraerla de sus palabras, se iría haciendo cada vez más palpable en estas notas de prensa hasta llegar a su culminación en la nota «La vaina de los diccionarios», de la que se tratará más adelante en este mismo artículo, en la que García Márquez hace completamente explícito su ideario con respecto a los diccionarios y, sobre todo, su actitud ante ellos.

Pero, para cerrar este apartado, lo que mejor permite hacerse una idea de la actitud que el escritor colombiano mantuvo hacia el DRAE durante la mayor parte de su vida, como siempre pasa con García Márquez, más que cualquier disertación sesuda, es precisamente una de sus anécdotas. Y es que en otra nota de prensa titulada «La literatura sin dolor» y publicada el 8 del 12 de 1982, cuenta una anécdota a la que ya se ha hecho referencia con anterioridad en este mismo trabajo: la de la encuesta que le realizó una revista colombiana sobre qué cinco libros escogería como los más significativos para él. Como ya se vio, uno de los escogidos por García Márquez sería un diccionario de la lengua castellana, pero, según sus propias palabras, «un Diccionario de la lengua castellana que no sea, desde luego, el de la Real Academia» ${ }^{39}$.

\section{«La mujer que escribió un diccionario»}

Seguidamente la atención se centrará en tres notas de prensa que se ocupan por completo de distintos aspectos de los diccionarios y el léxico del español y que, por lo tanto, merecen un análisis más pormenorizado que el que se ha dedicado a las alusiones dispersas al diccionario del periodo comprendido entre 1980 y 1984 que se han ido viendo hasta ahora. Conforme al orden cronológico de publicación, la primera de ellas sería la nota aparecida con el título «La mujer que escribió un diccionario» el 10 de febrero de 1981 con motivo del fallecimiento de María Moliner. García Márquez le dedicó una sentida nota de

${ }^{38}$ Véase J. C. Moreno Cabrera, «"Unifica, limpia y fija”. La RAE y los mitos del nacionalismo lingüístico español», en S. Senz y M. Alberte (eds.), op. cit., págs. 157-314.

${ }^{39}$ R. García Márquez, op. cit., pág. 348. 
prensa en la que dejaba clara su rendida admiración por la lexicógrafa española. En esa nota el escritor colombiano hablaba sobre la por aquel entonces semidesconocida figura histórica de María Moliner, contando sus orígenes, su vida familiar y, especialmente, el interesante y arduo proceso de gestación del diccionario que aquella escribió.

Pero, sobre todo, en esta nota García Márquez hace un juicio crítico del Diccionario de uso del español (1966-1967) de María Moliner, poniéndolo en valor por contraposición al resto de diccionarios y especialmente al DRAE. Es decir, García Márquez establece cuáles son en su opinión los principales méritos y cuáles los principales defectos del diccionario de María Moliner. En realidad, defectos solo señala uno: el hecho de no incluir «las mal llamadas malas palabras, que son muchas y tal vez las más usadas en la España de todos los tiempos» $»^{40}$. Según el novelista colombiano, «Es el defecto mayor de su diccionario, y María Moliner vivió lo bastante para comprenderlo, pero no lo suficiente para corregirlo».

En cambio, virtudes encuentra muchas, pues lo define como «el diccionario más completo, más útil, más acucioso y más divertido de la lengua castellana» ${ }^{41}$ y que, según aclara, «tiene dos tomos de casi 3.000 páginas en total, que pesan tres kilos, y viene a ser, en consecuencia, más de dos veces más largo que el de la Real Academia de la Lengua, y - a mi juicio-más de dos veces mejor» ${ }^{42}$. Pero, ¿en qué basaba el premio Nobel de 1982 esa opinión tan aparentemente radical? ¿Qué es lo que, a su juicio, hacía al Diccionario de uso del español de María Moliner tan especial? En primer lugar, su propia condición de diccionario de uso «que no sólo dice lo que significan las palabras, sino que indica también cómo se usan, y se incluyen otras con las que pueden reemplazarse» ${ }^{43}$, lo que lo convierte en un diccionario para escritores, tal como dijo la propia María Moliner. Al parecer, se había inspirado en el Learner's Dictionary, con el que ella misma había aprendido inglés. Es esto, desde luego, algo que lo diferenciaba del $D R A E$, pero que no parece en principio por sí solo un argumento suficiente como para catalogarlo como el más completo, pues por la época en la que García Márquez escribía esta nota ya existían otros diccionarios de uso del español. Y, desde luego, tampoco parece por sí solo un argumento lo suficientemente contundente como para defender que eso lo hacía más de dos veces mejor que el $D R A E$, puesto que este, simplemente, no ha tenido nunca la intención de ser un diccionario de uso, o un diccionario para escritores, sino que su propósito es otro.

En realidad, el elemento nuclear de la alabanza que García Márquez hace al diccionario de María Moliner y, lo que es más importante aún, el principal defecto que el novelista de Aracataca reprocha al DRAE es de una naturaleza

\footnotetext{
${ }^{40}$ R. García Márquez, loc. cit., pág. 59.

${ }^{41}$ R. García Márquez, loc. cit.

${ }^{42}$ R. García Márquez, loc. cit.

${ }^{43}$ R. García Márquez, loc. cit.
} 
mucho más profunda, más problemática y, sobre todo, mucho más polémica: este no es otro que el criterio con el que están tomadas las palabras a la hora de ser incluidas en él. En ese sentido, García Márquez afirma de manera admirativa que:

María Moliner tenía un método infinito: pretendía agarrar al vuelo todas las palabras de la vida. «Sobre todo las que encuentro en los periódicos», dijo en una entrevista. «Porque allí viene el idioma vivo, el que se está usando, las palabras que tienen que inventarse al momento por necesidad» ${ }^{4}$.

Para alguien como el escritor de Aracataca que, como ya se vio, declaraba abiertamente pelear a diario con las palabras ${ }^{45}$, alguien a quien no le importaba saltar de una variedad regional del español a otra con tal de encontrar la palabra que expresase de manera más certera lo que quería decir en cada momento ${ }^{46} \mathrm{y}$ que, si ninguna de las ya existentes le satisfacía plenamente, era capaz de crear él mismo una nueva sobre la marcha ${ }^{47}$, es lógico que el diccionario de María Moliner, con su pretensión de captar el idioma vivo, le pareciese el más completo, el más útil, el más acucioso y el más divertido. De hecho, la verdadera medida de lo útil que debió resultar el diccionario de María Moliner a lo largo de los años para el trabajo de escritor de García Márquez la da el propio novelista al comienzo de esta misma nota, cuando escribe que al enterarse de su muerte «Yo me sentí como si hubiera perdido a alguien que sin saberlo había trabajado para mí durante muchos años» ${ }^{48}$.

Frente al criterio de elección de María Moliner, basado en la vida de las palabras, el de la RAE, que García Márquez cataloga de «criterio de embalsamadores». En ese sentido, para el premio Nobel colombiano, en contraposición al diccionario de María Moliner, «En el diccionario de la Real Academia de la Lengua, en cambio, las palabras son admitidas cuando ya están a punto de morir, gastadas por el uso, y sus definiciones rígidas parecen colgadas de un clavo» ${ }^{49}$.Como tantas otras veces se percibe aquí un ataque furibundo a la RAE, a la que para terminar la nota no duda en catalogar de institución con una venerable tradición machista por haber rechazado en 1972 la candidatura de María Moliner como la primera mujer propuesta para ingresar en la academia $^{50}$. El último dardo a la RAE hace referencia a la hipocresía y la doble vara

${ }^{44}$ R. García Márquez, loc. cit.

${ }^{45}$ Véase la cita tomada de D'Amico y Facio, op. cit.

46 Tal como explica el propio García Márquez en la nota de prensa «La conduerma de las palabras», que se analizará justo a continuación.

${ }^{47}$ Véase en su famoso discurso Botella al mar para el dios de las palabras, cuando explica el caso de la palabra «condoliente» que, según él decía, todavía no se había inventado.

${ }^{48}$ R. García Márquez, op. cit., pág. 58.

${ }^{49}$ R. García Márquez, loc. cit., pág. 60.

${ }^{50}$ Afirmación errónea de García Márquez en su nota de prensa, por cierto, pues tal honor corresponde a Gertrudis Gómez de Avellaneda muchos años antes, en 1853. 
de medir de aquellos a los que denomina «los muy señores académicos» ${ }^{51}$, muchos de los cuales, pese a haber rechazado la candidatura de María Moliner, consultaban en público su diccionario sin ningún tipo de rubor.

Como se puede observar, aunque aparentemente se trata de una nota de prensa enteramente dedicada a hablarles a los lectores sobre la figura histórica de María Moliner, a describir sus métodos de trabajo y su pensamiento, con citas literales de sus propias palabras, en realidad, esta nota dice mucho más sobre las ideas del propio García Márquez respecto a los diccionarios que de las de María Moliner. Ahí precisamente radica su verdadero valor. Recapitulando, se pueden sacar ya dos primeras conclusiones sobre las teorías garciamarquianas respecto al diccionario:

1.) En primer lugar, que, para él, de entre todos los tipos de diccionarios, los que resultaban más útiles $\mathrm{y}$, por lo tanto, mejores eran los diccionarios de uso porque no solo dicen lo que significan las palabras, sino que, además, indican cómo se usan e incluyen otras con las que pueden reemplazarse.

2.) En segundo lugar, que, para él, el criterio que debían seguir los diccionarios era el de captar el lenguaje vivo, el de los periódicos y el de la calle, incluyendo las mal llamadas malas palabras, que, como él dice, son de las más numerosas y de las más usadas. Y, sobre todo, debían tratar de captarlas lo más pronto posible y no con la lentitud con la que, en su opinión, lo hacía el DRAE.

\section{«La conduerma de las palabras»}

Especialmente esta última cuestión del lenguaje vivo de la calle frente al lenguaje muerto del DRAE la retomaría García Márquez en otra nota del 19 de mayo de 1981, apenas tres meses después de la que se acaba de analizar, titulada «La conduerma de las palabras». Aunque en ella vuelven a mencionarse los diccionarios (el DRAE ${ }^{52}$, el Vox, el Diccionario de Americanismos de Alfredo Neves), no es, desde luego, una nota enteramente dedicada al diccionario como la anterior, ni como la que se analizará en el siguiente apartado. Pero sí que está dedicada por completo a hablar de cuestiones relacionadas con el léxico del español y vuelven a aparecer aspectos que conectan perfectamente con lo tratado anteriormente en «La mujer que escribió un diccionario».

Para empezar, García Márquez vuelve a atacar a la RAE por la lentitud con la que las palabras nuevas entran en su diccionario. Según dice el escritor colombiano, las palabras del español «[...] tienen que pasar cien años en el purgatorio del uso común antes de que la Real Academia les dé permiso para

\footnotetext{
${ }^{51}$ R. García Márquez, op. cit.

${ }^{52}$ Con otro dardo más o menos sutil de García Márquez hacia el DRAE, pues dice que «[...] yo no aprendí la palabra conduerma en ningún diccionario foráneo con pretensiones transnacionales [...]». R. García Márquez, loc. cit., págs. 104-105, en clara alusión a aquel. Por supuesto, la elección de palabras no es casual, sino que por el contrario estas están cargadas de sarcasmo.
} 
ser enterradas en el mausoleo de su diccionario» ${ }^{33}$. Hay que resaltar el uso del término enterradas en lugar de admitidas. En este sentido, el problema para García Márquez no era simplemente que las palabras tardaran mucho en ser admitidas por el DRAE, es que cuando lo hacían ya estaban casi en desuso, ya estaban prácticamente muertas y su inclusión en ese diccionario acababa siendo como enterrarlas en un mausoleo. En sus propias palabras «Para mí, el mejor idioma no es el más puro, sino el más vivo. Es decir: el más impuro» ${ }^{54}$. Y como ejemplo de ese lenguaje más vivo pone el de México, que califica como «el más imaginativo, el más expresivo, el más flexible» ${ }^{55}$. En cambio, lejos de cualquier chovinismo, carga sin piedad contra el cliché que parece ser existía en toda América latina de que en Colombia se hablaba el mejor castellano, el más puro. Para el escritor de Aracataca:

Los colombianos, que en los últimos tiempos hemos ganado tan mala fama en el mundo por tantas razones distintas, tenemos desde hace años la de hablar el castellano más puro. Dormimos en falsos laureles, pues en realidad hablamos por la calle una lengua muy bella, rica y útil, pero la que nos ha dado la fama no es ésa, sino la que recitan como loros nuestros académicos polvorientos y nuestros presidentes embalsa$\operatorname{mados}^{56}$

Una vez más, la postura de García Márquez está muy clara: la lengua bella, rica y útil es la que se habla en la calle en el tiempo presente, mientras que la del DRAE era la que utilizaban los académicos polvorientos y los presidentes embalsamados, es decir, una lengua anclada en el pasado, que no evolucionaba a la par que lo hace la manera de hablar de la gente de la calle y que, por lo tanto, se quedaba arrinconada cogiendo polvo, inmóvil e inmutable, como si estuviera embalsamada. De manera implícita, García Márquez a comienzos de la década de 1980 parecía estar reclamando ya que es el lenguaje vivo de la calle el que tendría que estar recogido en el diccionario, para lo cual haría falta una mayor celeridad por parte de las Academias a la hora de admitir su introducción en el mismo.

\section{«La vaina de los diccionarios»}

Pero si hay un texto absolutamente fundamental para comprender el pensamiento y actitud de García Márquez con respecto a los diccionarios en general y hacia el DRAE en particular es precisamente este que se va a analizar a continuación. Esta nota de prensa, publicada el 19 de mayo de 1982, es decir, un

\footnotetext{
${ }^{53}$ R. García Márquez, loc. cit.

${ }_{54}$ R. García Márquez, loc. cit., pág. 106.

55 R. García Márquez, loc. cit.

${ }^{56}$ R. García Márquez, loc. cit.
} 
año y tres meses después de «La mujer que escribió un diccionario», supuso sin duda la culminación de esa actitud cada vez más crítica a la que había llegado el escritor colombiano por aquella época y que se ha visto ya cómo se iba reflejando de manera cada vez más clara en las distintas alusiones que hacía a los diccionarios, especialmente al DRAE, en esas notas de prensa. Con este texto llegó García Márquez a un punto de no retorno, pues lo que hasta aquel momento habían sido alusiones dispersas que suponían dardos sueltos a la RAE, algunos de manera implícita, otros más explícitos, se convierte en este texto en una declaración formal de guerra contra la misma. Y es que la nota, como se verá a continuación, supone un claro alegato contra el carácter prescriptivo y normativo de los diccionarios y su supuesta autoridad para decirles a los hablantes de una lengua cuál es el significado de las palabras y qué palabras forman parte de esa lengua y cuáles no. Es decir, en esta nota García Márquez se centra sobre todo en una de las dos propiedades que años más tarde Del Valle ha considerado centrales en la glotopolítica: la normatividad (siendo la otra la indicialidad) ${ }^{57}$.

La contundente frase con la que comienza el texto no puede ser más clara y reveladora de esta actitud: «Uno de los placeres de la vida es encontrar las imbecilidades de los diccionarios $\rangle^{58}$. Tras semejante declaración de intenciones, García Márquez narra una vez más la consabida anécdota de cómo fue su abuelo quien le inculcó el hábito de consultar el diccionario para todo. Según el escritor de Aracataca:

Para mí, en especial, constituyen una cierta forma de venganza contra el destino, porque mi abuelo el coronel me enseñó desde muy niño que los diccionarios no sólo lo sabían todo, sino que además no se equivocaban nunca ${ }^{59}$.

Pero esta vez la cuenta desde una perspectiva completamente distinta, ya que aquí el énfasis no está puesto en lo saludable de dicho hábito, como había sucedido en otras ocasiones en que se había tenido conocimiento de la anécdota $^{60}$, sino todo lo contrario. Aquí lo que García Márquez cuenta, como él mismo reconoce como una especie de venganza, es la caída que se produjo al llegar a la edad adulta de un mito que él tenía bien arraigado desde su niñez: el de la supuesta infalibilidad de los diccionarios. De ahí que, siempre fiel a su estilo en el que prima la anécdota sobre el discurso abstracto, empiece por explicar el error garrafal que había en la portada del diccionario de su abuelo,

57 J. del Valle, «Lo político del lenguaje y los límites de la política lingüística panhispánica», Boletín de Filología, 49, 2, 2014, págs. 92-93.

${ }_{58}$ R. García Márquez, op. cit., pág. 262.

${ }^{59}$ R. García Márquez, loc. cit.

${ }^{60}$ Recuérdese que a esta misma anécdota ya se ha hecho referencia en páginas anteriores de este mismo artículo, pero contada por su amigo Plinio Apuleyo Mendoza en su libro entrevista a García Márquez El olor de la Guayaba. 
error que confundió al pobre hombre, como tantos otros errores de los diccionarios habrán confundido alguna vez a tanta gente:

El suyo, que era un mamotreto muy viejo y ya a punto de desencuadernarse, tenía pintado en el lomo un Atlas corpulento con la bola del mundo sobre los hombros. «Esto quiere decir que el diccionario tiene que cargar con el mundo entero», me decía mi abuelo, a quien, sin duda, no se le ocurrió nunca buscar la nota sobre Atlas en el propio diccionario. De haberlo hecho, se habría dado cuenta de que ese dibujo era un error muy grave. Atlas, en efecto, era uno de los titanes de la mitología griega que provocó una guerra contra los dioses, por lo cual lo condenó Zeus a sostener el firmamento sobre sus espaldas.

El firmamento, por supuesto, y no el mundo, como estaba dibujado en el lomo del diccionario, porque ni el propio Zeus sabía en sus tiempos que la Tierra era redonda como una naranja ${ }^{61}$.

Según él mismo cuenta, su abuelo nunca llegó a ser consciente de este error y él como niño tampoco, de manera que se le quedó para siempre el hábito de consultar para todo el diccionario «y debieron pasar muchos años antes de que descubriera con mi propia alma que no sólo los diccionarios no lo saben todo, sino que además cometen equivocaciones, casi siempre divertidas $\rangle^{62}$. Pero hay aquí un matiz a la tantas veces referida costumbre de García Márquez de mirar el diccionario para todo que nunca antes se le había visto contar, que aparece aquí por primera vez y que cambia completamente la perspectiva que se pudiera tener sobre la sujeción o incluso la sumisión del escritor colombiano hacia lo que dijeran los diccionarios: en esta ocasión explica que, después de muchos años de lidiar con ese compañero inseparable de trabajo que ya se ha dicho que el diccionario había sido para él, acabó por cambiar su manera de acercarse a él y de relacionarse con él. De modo que ya en aquella época, según sus palabras, «[...] consulto siempre el diccionario, pero no antes de escribir, sino después, para comprobar si estamos de acuerdo» ${ }^{63}$.

Todo lo anterior indica claramente que García Márquez, después de años de comprobar cómo los diccionarios a veces cometían errores garrafales en sus definiciones (como los casos que va a mencionar a continuación él mismo en esta nota), de ver cómo a veces las definiciones eran pésimas por imprecisas ${ }^{64}$, de encontrarse a veces las definiciones de dos términos que en el diccionario estaban intercambiadas ${ }^{65} \mathrm{y}$ de tantos años de viajar por todo el mundo hispanohablante y comprobar cómo gran parte del léxico que él iba conociendo por

\footnotetext{
${ }^{61}$ R. García Márquez, loc. cit.

${ }^{62}$ R. García Márquez, loc. cit.

${ }^{63}$ R. García Márquez, loc. cit.

${ }^{64}$ Recuérdese en este mismo trabajo el caso de la definición del DRAE para la palabra fauno.

${ }^{65}$ Recuérdese en este mismo artículo el caso de las definiciones del DRAE para los términos imaginación y fantasía.
} 
ese mundo no estaba recogido en los diccionarios ${ }^{66}$, ya no tenía la confianza en el diccionario que tuviera en su infancia. De modo que, como él mismo explicaba, «con el tiempo he terminado por confiar más en mi instinto del idioma, tal como se oye en la calle, y en las leyes infalibles del sentido común ${ }^{67}$.

Con respecto a cada uno de estos dos aspectos, instinto del idioma y sentido común, y a cómo constituyen dos parámetros que pueden ayudar a detectar esas imbecilidades de los diccionarios, va a darles a sus lectores García Márquez en su nota varios ejemplos muy ilustrativos. El primero tiene que ver con la elección de una palabra en un género distinto de aquel en el que aparece recogida en el diccionario. Así cuenta que:

El otro día, después de decidir, por mi cuenta y riesgo, que se puede decir pitoniso cuando el vidente es un hombre, descubrí que ningún diccionario incluye la palabra, aunque ninguno la prohíbe. El de la Real Academia la define así: «Sacerdotisa de Apolo que daba los oráculos en el templo de Delfos, sentada en el trípode». Una pizca de sentido común permitía pensar que la palabra no existe en masculino, porque eran mujeres quienes hacían en el templo de Delfos el hermoso oficio de adivinas, pero que nada se oponía a que se les llamara pitonisos si hubieran sido hombres, como los hay tantos en nuestro tiempo y, sobre todo, en nuestros medios de la Prensa ${ }^{68}$.

Como se puede apreciar, ante una duda sobre la posible utilización de un término sobre el que el diccionario no da una información precisa, fueron el instinto del idioma (después de decidir, por mi cuenta y riesgo) y el sentido común (Una pizca de sentido común) del propio García Márquez los que le llevaron a tomar una decisión, tras una argumentación basada en una lógica impecable. ¿Por qué entonces no estaba la palabra pitoniso en el diccionario ${ }^{69}$ ? El reproche a los autores del diccionario, aunque formulado de manera indirecta está ahí y es muy claro: porque no se habían molestado en aplicar, como había hecho él, ni el instinto del idioma ni el sentido común.

El segundo ejemplo que presenta García Márquez en su nota hace referencia a errores imperdonables en los diccionarios:

${ }^{66}$ Véase la nota de prensa «La conduerma de las palabras», en la que explica el significado de los mexicanismos cruda y hacerse bolas, que eran de uso común en México pero que no estaban recogidas en ningún diccionario.

${ }^{67}$ R. García Márquez, op. cit.

${ }^{68}$ R. García Márquez, loc. cit., págs. 262-263.

${ }^{69}$ En realidad no estaba porque, como es bien sabido, la Real Academia de la Lengua Española utiliza como criterio para la introducción de nuevos términos en el diccionario el uso extendido entre los hispanohablantes y se sirve del Corpus de Referencia del Español Actual (CREA) para comprobar ese posible uso extendido. En el caso de la palabra pitoniso, esta no se registra en el CREA antes de 1997 y desde entonces tampoco ha ganado mucha representación, pues solamente se registran siete casos, lo que además implica que ni siquiera la encendida defensa del término por parte de García Márquez en su nota ha contribuido excesivamente a popularizar el término. 
El más escandaloso de ellos me parece el de la inolvidable María Moliner, en su Diccionario de uso del español, cuando define la palabra dia: «Espacio de tiempo que tarda el Sol en dar una vuelta completa alrededor de la Tierra». [...] lo que ahora me interesa no es eso, sino la barbaridad de que sea el Sol el que da la vuelta completa alrededor de la Tierra, y no ésta sobre sí misma, como nos enseñaron en la escuela. El error, al parecer, tiene su origen en el diccionario de la Real Academia Española, que define el día de este modo: «Tiempo que el Sol emplea en dar, aparentemente, una vuelta a la Tierra $»^{70}$. La precaución del aparentemente no resuelve el enigma, porque no queda claro si los reales académicos quisieron decir que la cosa parece así, aunque en realidad no lo sea, o si quisieron decir que ellos no lo saben a ciencia cierta. De todos modos, el modesto Petit Larousse, que no se da ínfulas de nada, trae una definición diáfana: «Tiempo que tarda la Tierra en dar la vuelta sobre sí misma» ${ }^{71}$.

A pesar de que se ha visto que el escritor colombiano les tenía bastante más aprecio a María Moliner y a su diccionario que a la RAE y al suyo, se observa cómo García Márquez no duda en señalar en el diccionario de la primera un error de bulto del tipo del que cometía la portada del diccionario de su abuelo. Como él mismo dice, el error de María Moliner parece provenir directamente de la definición del $D R A E$, que es bastante ambigua al respecto. Y resulta llamativo que, en último término, García Márquez parece estar más irritado con la ambigua definición del $D R A E^{72}$ por el hecho de haber confundido a la inolvidable María Moliner, que con el propio error de María Moliner. En este caso, el ejemplo de definición diáfana y que no da lugar a ninguna posible mala interpretación es el del Petit Larousse, el más modesto de los tres. De todas formas, de manera también bastante sutil, hay otra crítica implícita en esta anécdota: y es la de que la mayoría de los diccionarios copian sin disimulo a los diccionarios anteriores e incorporan sus definiciones sin pararse a reflexionar

${ }^{70}$ La definición de día que podemos encontrar actualmente en la 23. edición del DLE es «Período de 24 horas, correspondiente al tiempo que la Tierra emplea en dar una vuelta completa sobre su eje», con lo cual se han subsanado los problemas que García Márquez señalaba en su nota de 1982.

${ }^{71}$ R. García Márquez, op. cit., pág. 263.

72 Parece ser que varios años más tarde, a comienzos de la década 1990, García Márquez volvió a la carga con esta cuestión en concreto. Según su biógrafo Gerald Martin, «Como para dar mayor realce a la dignidad y la respetabilidad engrosadas, y tal vez para impresionar a sus compatriotas de "la Atenas de Sudamérica", tras su visita a París, cuna de la mentalidad académica, lanzó una invectiva contra la Real Academia de la Lengua Española, responsable, según sostenía, de un "diccionario geocéntrico"» (G. Martin, op. cit., pág. 559). Desgraciadamente dicha invectiva debió pasar bastante desapercibida en la prensa de la época porque no ha quedado ningún testimonio que recoja directamente en qué consistió. El propio biógrafo alude a una noticia en el periódico mexicano Excelsior del 29 de enero de 1993. Pero lo cierto es que en ese breve texto titulado «Gabriel García Márquez. El diccionario geocentrista» es en realidad el anónimo periodista que lo escribe quien realiza su propio alegato contra el geocentrismo del DRAE. 
mucho sobre su validez, de manera que, en ocasiones, una mala definición o una definición incorrecta pasa de unos diccionarios a otros y se perpetúa en el tiempo. De hecho, esa misma crítica a los diccionarios en general y al DRAE en particular se desprende claramente de estas otras palabras que pronunció años más tarde en un discurso titulado Un manual para ser niño:

George Bernanos, escritor católico francés, dijo: «Toda vocación es un llamado». El diccionario de Autoridades, que fue el primero de la Real Academia en 1726, la definió como «la inspiración con que Dios llama a algún estado de perfección». Era, desde luego, una generalización a partir de las vocaciones religiosas. La aptitud, según el mismo diccionario, es «la habilidad y facilidad y modo para hacer alguna cosa». Dos siglos y medio después, el diccionario de la Real Academia conserva estas definiciones con retoques mínimos ${ }^{73}$.

En cambio, el tercer ejemplo que aporta García Márquez en «La vaina de los diccionarios» hace alusión precisamente al caso contrario, a cuando los diccionarios se dan cuenta de que una determinada definición resulta ridícula (a veces incluso por el exceso de precisión de la misma) y la corrigen en una edición posterior. Para ilustrarlo cuenta el caso de la famosa definición de la palabra perro que apareció durante muchos años en el diccionario de la Real Academia:

«Mamífero doméstico de la familia de los cánidos, de tamaño, forma y pelaje muy diversos, según las razas, pero siempre con la cola de menor longitud que las patas posteriores, una de las cuales levanta el macho para orinar». Se prestó a tantas burlas esta precisión excesiva - y entre ellas una muy feroz e inteligente de Guillermo Cabrera Infante en su novela Tres tristes tigres - , que en las ediciones más recientes del diccionario de la Real Academia ya los perros no levantan la pata posterior para orinar, aunque sigan haciéndolo en la vida real74.

El siguiente reproche que hace García Márquez a los diccionarios es el de las definiciones de los colores que, según él, es otra cuestión que siempre le inquietó bastante del DRAE. Y pone el ejemplo de la definición que hace dicho diccionario sobre el color amarillo:

«Del color semejante al del oro, el limón, la flor de la retama, etcétera». A mi modo de ver las cosas desde la América Latina, el oro era dorado, no conocía las flores de la retama, y el limón no era amarillo, sino verde. Desde antes me había llamado la atención el romance de

73 Documentos de la Misión, Ciencia, Educación y Desarrollo: Educación para el Desarrollo. Tomo 2. Presidencia de la República-Consejería para el Desarrollo Institucional, Colciencias, Santafé de Bogotá D. C., 1995.

${ }^{74}$ R. García Márquez, op. cit. 
García Lorca: «En la mitad del camino cortó limones redondos, /y los fue tirando al agua hasta que la puso de oro».

Necesité muchos años para viajar a Europa y darme cuenta de que el diccionario tenía razón, porque, en realidad, los limones europeos son amarillos ${ }^{75}$

Este breve reproche resulta en realidad interesantísimo porque, si apenas dos párrafos antes García Márquez acusaba al DRAE de geocentrista, en este lo está acusando indirectamente de eurocentrista. Por más que al final diga que el diccionario tenía razón, especifica que no tenía razón porque el amarillo sea en efecto el color de (todos) los limones, sino porque los limones europeos son amarillos. Lo que parece estar diciendo es que en este caso no ve una voluntad de imponer el criterio de la RAE en la definición, solamente falta de conocimiento de otras realidades del mundo por parte de quienes la han hecho. En realidad, la cuestión no es baladí ya que el ejemplo retoma una cuestión que García Márquez había tratado ya más por extenso en otra nota de prensa anterior titulada «Algo más sobre literatura y realidad», que había sido publicada casi un año antes, en julio de 1981: la del problema que supone la insuficiencia de las palabras para describir la realidad del continente americano:

Un problema muy serio que nuestra realidad desmesurada plantea a la literatura es el de la insuficiencia de las palabras. Cuando nosotros hablamos de un río, lo más lejos que puede llegar un lector europeo es a imaginarse algo tan grande como el Danubio, que tiene 2.790 kilómetros. Es difícil que se imagine, si no se le describe, la realidad del Amazonas, que tiene 5.500 kilómetros de longitud. Frente a Belén del Pará no se alcanza a ver la otra orilla, y es más ancho que el mar Báltico. Cuando nosotros escribimos la palabra «tempestad», los europeos piensan en relámpagos y truenos, pero no es fácil que estén concibiendo el mismo fenómeno que nosotros queremos representar. Lo mismo ocurre, por ejemplo, con la palabra «lluvia». En la cordillera de los Andes, según la descripción que hizo para los franceses otro francés llamado Javier Marimier, hay tempestades que pueden durar cinco meses. «Quienes no hayan visto esas tormentas», dice, «no podrán formarse una idea de la violencia con que se desarrollan. Durante horas enteras los relámpagos se suceden a manera de cascadas de sangre y la atmósfera tiembla bajo la sacudida continua de los truenos, cuyos estampidos repercuten en la inmensidad de la montaña». La descripción está muy lejos de ser una obra maestra, pero bastaría para estremecer de horror al europeo menos crédulo.

De modo que sería necesario crear todo un sistema de palabras nuevas para el tamaño de nuestra realidad ${ }^{76}$.

\footnotetext{
${ }^{75}$ R. García Márquez, loc. cit.

${ }^{76}$ R. García Márquez, loc. cit., pág. 119.
} 
Dicha insuficiencia proviene en último término del hecho de que históricamente el español como lengua ya existía antes de llegar a América y ser impuesto a sus pobladores. De manera que los significados de la mayoría de sus palabras, basadas única y exclusivamente en la realidad conocida hasta entonces, que era la europea, ya estaban bien consolidados y asentados en el imaginario colectivo. En el imaginario colectivo europeo, evidentemente. Como se puede apreciar, en esta nota García Márquez limita el alcance del problema a que cuando un europeo lee una de esas palabras (río, lluvia, tempestad) escrita por un autor latinoamericano, lo único que puede hacer es activar de manera natural su marco de referencia para esa palabra, marco de referencia que se construye sobre la realidad que conoce, que es la europea, pero que no es desde luego la única realidad que existe en el mundo. En este sentido, esta nota no supone ningún reproche por parte de García Márquez a los lectores europeos, puesto que cada persona solo puede aplicar el significado a cada palabra conforme a su propio marco de referencia, a la realidad que esa persona conoce. Y eso funciona así universalmente, no es un problema exclusivo de los europeos. De hecho, ya se vio cómo en la nota «La vaina de los diccionarios» García Márquez reconocía que, durante muchos años, a su modo de ver las cosas desde América Latina, el limón no era amarillo sino verde y que, solo tras viajar a Europa, supo que los limones podían ser verdes como en América o amarillos como en Europa. Es decir, hasta que no amplió su marco de referencias sobre el limón no pudo incorporar a su acepción de la palabra limón el color amarillo. Por lo tanto, nada que reprochar hasta ahí. Simplemente constatación de un problema de comunicación entre europeos y americanos.

Sin embargo, en la nota «La vaina de los diccionarios» sí que hay un claro reproche implícito con la anécdota de la definición del DRAE del amarillo como Del color semejante al del oro, el limón, la flor de la retama, etcétera. García Márquez dice en la nota que dicha definición le inquietaba porque no conocía las flores de la retama y para él los limones eran verdes ${ }^{77}$. Es decir, no había nada en esa definición que se correspondiese con su propio marco de referencias como hablante latinoamericano del español, porque dicha definición estaba hecha desde la perspectiva de los académicos españoles y de su marco de referencias, que es el europeo, y no concordaba en absoluto con el marco de referencias de un hablante latinoamericano del español. El reproche implícito es que el español es el vehículo de comunicación no solo de los hablantes de español europeos, sino también de los millones de hablantes de español

77 La definición de la palabra amarillo ha cambiado de la que venía en la 19a edición del DRAE (1970) «Del color semejante al del oro, el limón, la flor de la retama, etcétera», a la que aparece en la 23. del $D L E$ (2014) «Dicho de un color: Semejante al del oro o al de la yema de huevo, y que ocupa el tercer lugar en el espectro luminoso». Curiosamente lo que ha variado en la definición son precisamente los elementos que García Márquez consideraba inadecuados en ella: los ejemplos de cosas que son de color amarillo. El polémico limón que puede ser amarillo o verde y la flor de la retama que puede no ser conocida por muchos hispanohablantes han sido sustituidas por la yema de un huevo, que todo el mundo conoce y es amarilla en todas partes del mundo. 
latinoamericanos. Y si la RAE y su diccionario suponían la máxima autoridad a la hora de decirles a todos los hispanohablantes lo que significaba una palabra, sus definiciones no podían estar hechas solamente desde la perspectiva europea de los académicos españoles. No cabe la menor duda de que con esta crítica García Márquez se estaba erigiendo sin saberlo en precursor de toda una corriente dentro de los estudios glotopolíticos: aquella que aborda la función política de la lengua principalmente desde los estudios lexicográficos y que denuncia, como se hace en los trabajos de Lauria, que «la producción lexicográfica mono-lingüe se relaciona indisolublemente con la idea de nación $\rangle^{78}$. Lauria se interesa por el estudio del diccionario de Tobías Garzón de 1910, y establece que en los diccionarios monolingües se configura un imaginario nacional, de manera que su elaboración supone:

[...] un acto glotopolítico en la medida en que exige, por un lado, la toma de decisiones en torno a asuntos como la norma, el uso, la prescripción y descripción, el cambio lingüístico, la corrupción idiomática, los barbarismos, calcos, préstamos, entre otros; por otro lado, evidencia «fenómenos que pertenecen al ámbito político de la coyuntura histórica en la que se inserta» ${ }^{79}$.

Con una anécdota tan simple como la de la definición de los colores, García Márquez estaba reprochando a la RAE que, efectivamente, la 19. edición del DRAE evidenciaba aún fenómenos que pertenecían al ámbito político de la coyuntura histórica en la que se había realizado, que era aún una época de primacía de la variedad castellana peninsular como único estándar prestigioso en todo el mundo hispanohablante, cuando ya para la época en que escribe su nota el premio Nobel colombiano la situación estaba virando hacia un modelo panhispánico que no haría sino consolidarse en las décadas siguientes ${ }^{80}$.

En el siguiente párrafo, tras tanta crítica y tanta mofa al DRAE, el escritor de Aracataca le reconoce al menos un mérito a dicho diccionario: las definiciones de las plantas, que califica todas de excelentes y hechas por «un gran escritor escondido en la Real Academia ${ }^{81}$. Pero, probablemente, el elemento más innovador, original y revolucionario de esta nota esté en el factor que introduce García Márquez ya en el penúltimo párrafo: la cuestión del significado subjetivo que, tal como él explica, es «una dimensión de las palabras que los diccionarios no pueden establecer ${ }^{82}$, pero que, indudablemente, influye en

78 D. Lauria, «Los discursos sobre la lengua (1900-1910). Un abordaje desde la teoría del discurso social». Trabajo presentado en el IV Coloquio de Investigadores en Estudios del Discurso y I Jornadas Internacionales sobre Discurso e Interdisciplina, Córdoba, 2009, pág. 2.

79 J. A. Molina Ríos, «Estudios del lenguaje desde una perspectiva glotopolítica», Signo y Pensamiento, 38 (74), 2019, págs. 2027-2731.

${ }^{80}$ Véase en ese sentido F. Moreno Fernández, «Los modelos de lengua. Del castellano al panhispanismo», en A. M. Cestero (ed.), X Aniversario del Máster de Enseñanza de Español para Extranjeros, Universidad de Alcalá, Alcalá de Henares, 2006, págs. 75-94.

${ }^{81}$ R. García Márquez, op. cit., pág. 263.

${ }^{82}$ R. García Márquez, loc. cit., pág. 264. 
la elección de un término u otro por parte del hablante. Y para ilustrar a qué se refiere pone el ejemplo de la diferencia que existe entre un barco y un buque. Según el premio Nobel de 1982:

El diccionario de la Academia describe el buque de este modo: «Barco con cubierta que, por su tamaño, solidez y fuerza, es adecuado para navegaciones o empresas marítimas de importancia». Esto permite preguntarse, en primer término, qué empresas marítimas puede acometer un buque sin tener que navegar, puesto que las dos funciones las establece el diccionario como diferentes. Y permite pensar, en segundo término, que un buque no sirve para empresas fluviales, porque sólo se dice que sirve para empresas marítimas ${ }^{83}$. Pero lo importante está dicho, y es que un barco es un buque. Sin embargo, para mí hay una diferencia subjetiva que me obliga a utilizar ambas palabras con un sentido diferente. En casa de los abuelos, los barcos eran sólo los de mar, como los que transportaban el banano desde Santa Marta hasta Nueva Orleans. En cambio, los buques eran los del río Magdalena, con dos chimeneas, alimentados con leña e impulsados con una rueda de madera en la popa. Para ambos, de todos modos, había un nombre genérico: vapor ${ }^{84}$.

Esta cuestión del significado subjetivo de las palabras es algo que en esta nota aparece apenas apuntado y ejemplificado, pero aún no desarrollado. Pero, en cualquier caso, aunque no sea de forma explícita y abierta, sí que se puede observar claramente cómo toda la nota gira ya en torno a la defensa de la subjetividad del hablante y su criterio personal para usar las palabras como estime oportuno frente a la aparente tiranía impositiva del diccionario. Esta defensa ha sido posteriormente una de las principales preocupaciones de la glotopolítica en su acercamiento a la normatividad tal como explica José del Valle cuando afirma que:

[...] al anclar el estudio del funcionamiento del lenguaje en la acción conjunta de la referencialidad y la indicialidad, se problematiza la transparencia semántica que se le supone a las lenguas, sobre todo a aquellas que están altamente codificadas. El pleno significado de los enunciados, como acabamos de decir, depende no de una relación biunívoca y fija entre significantes y significados sino de las condiciones - de orden pragmático, cultural, social, político- en que se producen. De ahí que los individuos hablen (o escriban) según su orientación hacia el contexto de la interacción, según el modo en que lo conciban y según como quieran posicionarse en relación con él. Al usar el lenguaje siempre orientamos nuestra producción verbal en función de un contexto de normas socialmente constituidas y esta orientación liga inexorablemente lenguaje y

${ }^{83}$ La definición de buque que critica García Márquez en su artículo y que aparecía en la 19a. edición del DRAE (1970) ha pasado en la 23. edición del DLE (2014) a un más escueto «Barco de gran tonelaje con cubierta o cubiertas. Buque de guerra, cisterna».

${ }^{84}$ R. García Márquez, op. cit. 
metalenguaje, es decir, la práctica lingüística a las expectativas que puedan existir sobre el modo en que van a ser interpretadas ${ }^{85}$.

En este sentido, el último párrafo de la nota de García Márquez supone un colofón perfecto, ya que cierra el círculo al retomar uno de los dos aspectos con los que prácticamente iniciaba García Márquez su disquisición con respecto a la relación entre el diccionario y el uso real de las palabras por parte de los hablantes: el instinto del idioma. Según cuenta en él, a su amigo Argos, al que ya había aludido también en el párrafo anterior, no le pareció correcta la utilización del verbo perecer aplicada a un herido a puñaladas que murió horas después en el hospital:

A Argos no le parecía correcto, pero no sabía por qué, y a mí tampoco me parece, y yo tampoco sé por qué. Hay un instinto del idioma que indica, sin lugar a dudas, que los enfermos de los hospitales no perecen, sino que se mueren, cualquiera sea el motivo, a menos que les caiga el techo encima. En cambio, una persona puede haber perecido en una catástrofe aérea, si fue esa la causa de su muerte, aunque ésta haya ocurrido, en realidad, varios días después en el hospital. Casi me atrevería a decir que el acto de perecer puede no ser simultáneo con el de morir, aunque el uno tiene que ser consecuencia del otro. Pero, por fortuna, yo no soy diccionario para atreverme a decir tanto ${ }^{86}$.

Una vez más, se puede observar claramente cómo es su instinto del idioma el que le indica cuál es la utilización apropiada del término perecer, aunque ni siquiera sepa por qué es así. Y, desde luego, está dejando claro que esos matices de utilización de la palabra no se encuentran en ningún diccionario. Hay que recordar que al comienzo de la nota García Márquez hablaba de que a la hora de utilizar una palabra su confianza estaba más en su «instinto del idioma» y el «sentido común» que en lo que dijera el diccionario. Por lo tanto, lo que de manera implícita está diciendo el premio Nobel colombiano es que esos dos aspectos están ausentes de los diccionarios. Estos ni tienen instintos ni pueden aplicar el sentido común porque ambos son patrimonio de los seres vivos, que son quienes hacen un uso práctico del idioma. En cambio, como se recordará, para García Márquez los diccionarios no tenían nada de vivos, pues los consideraba auténticos mausoleos en los que se enterraba a las palabras a punto de morir. Los diccionarios eran, por lo tanto, para él esquemas mentales preconcebidos en los que quienes los elaboran tratan de meter, aunque sea a la fuerza, la realidad en que vivimos. En definitiva, un trabajo intelectual ${ }^{87}$

85 J. del Valle, op. cit.

${ }^{86}$ R. García Márquez, op. cit.

${ }^{87}$ Como ya se ha mencionado en varias ocasiones a lo largo de este mismo trabajo, García Márquez sintió siempre un prejuicio manifiesto por las teorizaciones estériles y los intelectuales: «Siempre he tenido un prejuicio contra los intelectuales, entendiendo por intelectual a alguien que tiene un esquema mental preconcebido y trata de meter dentro de él, aunque sea a la fuerza, 
que resulta estéril si el hablante no le suma su instinto del idioma y su sentido común.

No cabe duda de que es una visión bastante rompedora de cómo funcionan y se deben utilizar tanto las palabras como los propios diccionarios. Y es que ambos parámetros, instinto del idioma y sentido común, quedan fuera del acercamiento académico que suelen tener los lexicógrafos a las palabras, ya que ambos parecen estar relacionados con la subjetividad de las palabras, tanto en su significado como en su aplicación, mientras que la lexicografía, especialmente a través de la elaboración de diccionarios se ocupa única y exclusivamente del significado objetivo de las palabras. Por lo tanto, nadie se ocupa del significado subjetivo de las palabras. Existía ahí un vacío normativo, un vacío crítico. García Márquez se dio cuenta de ello y a partir de un determinado momento se convirtió en una de sus mayores preocupaciones con respecto a los diccionarios, una de las cuestiones sobre las que más reflexionó en esos años, adelantándose en varios años a la preocupación de los estudios de glotopolítica sobre el tema.

\section{Conclusiones}

A pesar de que, como se ha explicado en este trabajo, los diccionarios fueron sus principales instrumentos de trabajo desde que su abuelo le inculcara la costumbre de consultar en ellos todo lo que no supiera, a pesar de que ya se vio que él mismo decía que no hubiera podido escribir su obra sin la ayuda del diccionario, en este artículo se ha mostrado cómo la posición de García Márquez con respecto a este, lejos de ser de rendida admiración, devoción y sumisión a todo lo que dijeran, fue evolucionando tras tantos años de tratar con ellos hacia una actitud cada vez más crítica con los muchos defectos que les encontraba y rebelde hacia su supuesta autoridad. Esta actitud alcanzó su cénit durante la primera mitad de la década de 1980.

Hemos visto cómo sus ideas consistían, sobre todo, en una serie de problemas que el premio Nobel colombiano, desde su perspectiva de escritor, detectaba en los diccionarios de su época y quiso de alguna manera señalar a modo de denuncia. Evidentemente García Márquez no era un gramático, ni un lexicógrafo, ni pretendía serlo. Pero consideraba que, aunque escritores y gramáticos eran, por supuesto, oficios distintos que se servían incluso de una dialéctica diferente, ambos oficios eran igualmente importantes para la configuración de la lengua. Estas palabras que dijo en una entrevista concedida a Joaquín Estefanía en 1997 a raíz de la polémica de la ortografía sirven igualmente para explicar su actitud de denuncia ante los problemas del diccionario:

la realidad en que vive» (R. García Márquez, loc. cit., pág. 156). Como se puede comprobar, nuestra elección de palabras en estas últimas cuatro líneas no es casual. 
La raíz de esta falsa polémica es que somos los escritores, y no los gramáticos y lingüistas, quienes tenemos el oficio feliz de enfrentarnos y embarrarnos con el lenguaje todos los días de nuestras vidas. Somos los que sufrimos con sus camisas de fuerza y cinturones de castidad. A veces nos asfixiamos, y nos salimos por la tangente con algo que parece arbitrario, o apelamos a la sabiduría callejera [...].

El deber de los escritores no es conservar el lenguaje sino abrirle camino en la historia. Los gramáticos revientan de ira con nuestros desatinos, pero los del siglo siguiente los recogen como genialidades de la lengua. De modo que tranquilos todos: no hay pleito. Nos vemos en el tercer milenio ${ }^{88}$.

No cabe duda de que, vistas desde la perspectiva actual, dichas palabras resultan ciertamente proféticas, pues es evidente que algunos de los principales problemas y defectos que García Márquez señalaba especialmente en la $19^{a}$ edición del $D R A E$ (1970) en la década de 1980 hoy en día ya no se dan, o al menos se han hecho esfuerzos importantes por parte de la Academia para tratar de solucionarlos o de matizarlos en la 23. edición del DLE (2014). Y no se trata solo de aspectos puntuales, como la corrección de alguna definición señalada como deficiente por García Márquez, caso de las palabras amarillo o buque, por poner solo dos ejemplos, sino de cuestiones de mayor calado que han supuesto una modificación importante en la política de la institución en los últimos treinta años.

Un primer ejemplo se encuentra en lo referente al reconocimiento normativo del español de América y todo lo que tiene que ver con que se tenga en cuenta la perspectiva de los hablantes hispanoamericanos a la hora de confeccionar los recursos de la RAE, tales como su diccionario, que ya se vio que era uno de los aspectos que preocupaban a García Márquez ya en la década de 1980 en notas como «La vaina de los diccionarios» o «La conduerma de las palabras». Es incuestionable que en los últimos veinte años se han estrechado vínculos entre las diversas academias de la lengua y el esfuerzo conjunto de la Asociación de Academias de la Lengua ha dado lugar a iniciativas como el Diccionario panhispánico de dudas ${ }^{89}$ (2005), a un Diccionario de la lengua española (2001) que, según reza en la web de la RAE, tenía entre sus novedades «la incorporación de un gran número de voces y acepciones del español de América $»^{90}$, y en 2010 al Diccionario de americanismos de la ASALE. De hecho, las propias instituciones bautizaron este movimiento como una política lingüística panhispánica y la describieron así:

88 J. Estefanía, «De camisas de fuerza y cinturones de castidad», El país 13/04/1997.

${ }^{89}$ Calificado en el «Preámbulo» de la 23. edición del Diccionario de la lengua española de la RAE como una obra que desde tiempo atrás se sentía como necesaria. Ver: $<$ http://dle.rae.es/ $>$.

90 Ver: <http://www.rae.es/recursos/diccionarios/diccionarios-anteriores-1726-2001/diccionariode-la-lengua-espanola-2001>. 
Las funciones atribuidas tradicionalmente a las Academias de la Lengua consistían en la elaboración, difusión y actualización de los tres grandes códigos normativos en los que se concentra la esencia y funcionamiento de cualquier lengua y que aseguran su unidad: la Ortografía, el Diccionario y la Gramática. Hasta hace algunos años, el modo de alcanzar esos objetivos se planteaba desde el deseo de mantener una lengua 'pura', basada en los hábitos lingüísticos de una parte reducida de sus hablantes, una lengua no contaminada por los extranjerismos ni alterada por el resultado de la propia evolución interna. En nuestros días, las Academias, en una orientación más adecuada y también más realista, se han fijado como tarea común la de garantizar el mantenimiento de la unidad básica del idioma, que es, en definitiva, lo que permite hablar de la comunidad hispanohablante, haciendo compatible la unidad del idioma con el reconocimiento de sus variedades internas y de su evolución ${ }^{91}$.

En estas mismas palabras encontramos también una referencia al cambio de perspectiva de la RAE respecto a otra de las cuestiones que vimos que más le criticaba García Márquez a su diccionario: el de la obsesión de la Academia por la conservación de la pureza de la lengua, cuando, recordemos, para el escritor de Aracataca, «el mejor idioma no es el más puro, sino el más vivo. Es decir: el más impuro». En este sentido, no cabe duda de que en las últimas décadas el criterio de las academias a la hora de permitir el acceso de las palabras al diccionario ha sufrido una evolución que va en consonancia con el aspecto en el que, recordemos, más crítico se mostró García Márquez en la década de los ochenta con la RAE: la lentitud excesiva a la hora de permitir a las nuevas palabras entrar en el diccionario. No cabe duda de que, en los últimos años, la creación por parte de esta de bancos de datos como el CREA o el CORPES XXI ha facilitado enormemente la tarea a los académicos y les ha permitido agilizar el proceso de validación necesario para permitir la introducción de las palabras en el DRAE. Del mismo modo que la virtualización de este último recurso ha permitido una mayor flexibilidad a la hora de combatir el problema de la desactualización al que se tiene que enfrentar todo diccionario, tal como señalaba García Márquez, y ha permitido que actualmente las palabras no tarden tanto en llegar al diccionario que cuando lo hagan estén ya a punto de morir, tal como denunciaba García Márquez que ocurría a comienzos de la década de 1980.

Incluso ese carácter restrictivo del $D R A E$ que llevara a García Márquez a denominarlo esperpento represivo y a poner en duda su supuesta autoridad para decirles a los hablantes de la lengua qué palabras formaban parte del español y cuáles no, ha ido evolucionando, matizándose y suavizándose en las últimas décadas, hasta llegar a la situación actual en la que la RAE se preocupa de hacer cada vez más hincapié en su carácter orientador en cuanto al uso de las palabra

${ }^{91}$ ASALE, La nueva política lingüistica panhispánica, Real Academia Española, Madrid, 2004, pág. 3. 
y no impositivo, en intentar hacer compatible su función normativa con una perspectiva más descriptiva de la lengua española que prescriptiva92.

En este artículo no se pretende decir, por supuesto, que todos estos cambios que se han señalado sean mérito exclusivo de García Márquez, ni que se hayan producido como una reacción directa a los ataques del escritor de Aracataca a la RAE. Es obvio que mucha más gente habrá influido a lo largo de los años en ese proceso evolutivo que se ha ido dando en la política de la Academia hacia esos temas. Pero, aunque no sea el objetivo de este trabajo cuantificar el grado de influencia que las ideas de García Márquez hayan podido ejercer en la evolución posterior de los diccionarios ni del español normativo, no se puede negar que su claro posicionamiento glotopolítico tenía un peso específico muy superior al de la mayoría de sus contemporáneos. En este sentido, ya señalaba Henri Boyer que las intervenciones glotopolíticas «[...] se inscriben en un interdiscurso más o menos prolijo sobre la(s) lengua(s) de la comunidad y su(s) uso(s)», y que éstas:

[...] pueden ser hechas por individuos (personalidades más o menos conocidas, en general), grupos y/o asociaciones de militantes de la lengua, incluso partidos políticos: ellas tienen a menudo una fuerte dimensión reivindicativa y polémica que se apoyan en una ideología identitaria y en una opción política de tipo regionalista o nacionalitaria93.

Es evidente que el Premio Nobel colombiano por su fama y prestigio mundiales no era cualquier persona, que cada palabra que escribía era leída por millones de hispanohablantes y, por lo tanto, era un creador de opinión. De modo que, como voz autorizada que era, su denuncia tenía mucho más peso que la de la mayoría de los hablantes y podía ejercer mucha más presión sobre esas políticas de la RAE ${ }^{94}$.

En cualquier caso, de lo que no cabe duda es del carácter innovador para la época y claramente progresista que tenían las ideas de Gabriel García

92 Véase en ese sentido el apartado «La legitimidad normativa de las academias: descriptivismo, autoridad y consenso», en J. del Valle, op. cit., págs. 96-101.

${ }_{93}$ H. Boyer, "Conflit d'usages, conflit d'images», en H. Boyer (ed.), Plurilinguisme: «contact» ou «conflit» de langues?, L'Harmattan, París, 1997. Se toma la cita de E. Narvaja de Arnoux, "La glotopolítica: transformaciones de un campo disciplinario», en A. Rubione (coord.), Lenguaje: teorías y prácticas, Gobierno de la Ciudad de Buenos Aires e Instituto Superior del Profesorado, Buenos Aires, 2000, pág. 16.

${ }^{94}$ En ese sentido resulta muy revelador el hecho de que, a pesar todos los ataques directos de García Márquez al DRAE a lo largo de las décadas de 1980 y 1990, a pesar de todas las proclamas revolucionarias sobre la ortografía y la gramática que tantas ampollas levantaban entra los gramáticos y académicos, la RAE, lejos de devolverle los ataques e iniciar así una guerra abierta, a partir de mediados de la década de 1990 hiciese todo lo que estuviese en su mano por congraciarse con él y lo colmase de reconocimientos. Era sin duda un reconocimiento sincero y merecido a su aportación a la lengua española. Pero no es menos cierto que a la RAE no le convenía tener por más tiempo como «enemigo» a una figura de la talla de García Márquez que con los años no hacía más que acumular más y más prestigio mundial... 
Márquez sobre los diccionarios de la lengua española que se han analizado en este trabajo. De modo que, retomando las palabras premonitorias del propio escritor colombiano en la entrevista con Joaquín Estefanía que se han citado antes, se puede concluir que dichas ideas sobre los diccionarios de la lengua española probablemente serían percibidas como desatinos por los gramáticos de la época, pero es incuestionable que le fueron abriendo camino en la historia a la lengua española y es probable que lo vayan a seguir haciendo en los años próximos, ya que vistas desde la perspectiva del siglo XXI pueden ser consideradas como auténticas genialidades de la lengua. 